\title{
Fatty acid composition and bacterial community changes in the rumen fluid of lactating sheep fed sunflower oil plus incremental levels of marine algae
}

\author{
P. G. Toral, ${ }^{\dagger} \dagger^{1}$ A. Belenguer, ${ }^{\star}$ K. J. Shingfield,, G. Hervás, ${ }^{*}$ V. Toivonen, $\dagger$ and P. Frutos ${ }^{*}$ \\ *Instituto de Ganadería de Montaña (CSIC-Universidad de León), Finca Marzanas s/n, 24346 Grulleros, León, Spain \\ †Animal Production Research, MTT Agrifood Research Finland, FI-31600, Jokioinen, Finland
}

\begin{abstract}
Supplementation of ruminant diets with plant oils and marine lipids is an effective strategy for lowering saturated fatty acid (FA) content and increasing the concentration of cis-9,trans-11 conjugated linoleic acid and long-chain n-3 FA in ruminant milk. However, changes in populations of ruminal microorganisms associated with altered biohydrogenation of dietary unsaturated FA are not well characterized. Twenty-five lactating Assaf ewes were allocated at random to 1 of 5 treatments composed of dehydrated alfalfa hay and concentrates containing no additional lipid (control), or supplemented with $25 \mathrm{~g}$ of sunflower oil and 0 (SO), $8\left(\mathrm{SOMA}_{1}\right), 16\left(\mathrm{SOMA}_{2}\right)$, or $24\left(\mathrm{SOMA}_{3}\right) \mathrm{g}$ of marine algae $/ \mathrm{kg}$ of diet dry matter. On d 28 on diet, samples of rumen fluid were collected for lipid analysis and microbial DNA extraction. Appearance and identification of biohydrogenation intermediates was determined based on complementary gas chromatography and $\mathrm{Ag}+-\mathrm{HPLC}$ analysis of FA methyl esters. Total bacteria and the Butyrivibrio group were studied in microbial DNA by terminal RFLP analysis, and real-time PCR was used to quantify the known Butyrivibrio bacteria that produce trans-11 18:1 or 18:0. Dietary supplements of sunflower oil alone or in combination with marine algae altered the FA profile of rumen fluid, which was associated with changes in populations of specific bacteria. Inclusion of marine algae in diets containing sunflower oil resulted in the accumulation of trans 18:1 and 10-O-18:0 and a marked decrease in 18:0 concentrations in rumen fluid. At the highest levels of supplementation $\left(\mathrm{SOMA}_{2}\right.$ and $\left.\mathrm{SOMA}_{3}\right)$, marine algae also promoted a shift in ruminal biohydrogenation pathways toward the formation of trans-10 18:1 at the expense of trans-11 18:1. Changes in the concentration of biohydrogenation intermediates were not accompanied by significant variations in the abundance of known cultivated ruminal bacteria capable of hydrogenating unsaturated
\end{abstract}

Received May 22, 2011.

Accepted October 8, 2011.

${ }^{1}$ Corresponding author: pg.toral@eae.csic.es
FA. However, certain bacterial groups detected by terminal RFLP (such as potentially uncultured Lachnospiraceae strains or Quinella-related bacteria) exhibited variations in their relative frequency consistent with a potential role in one or more metabolic pathways of biohydrogenation in the rumen.

Key words: lactating ewe, marine algae, ruminal bacteria, biohydrogenation intermediate

\section{INTRODUCTION}

The inclusion of plant oils rich in 18:2n-6 and fish oil or marine algae (MA) in the diet is an effective nutritional strategy to increase concentrations of cis9,trans-11 conjugated linoleic acid (CLA) and 22:6n-3 in bovine (AbuGhazaleh et al., 2002; Shingfield et al., 2006; Invernizzi et al., 2010) and ovine milk (Reynolds et al., 2006; Toral et al., 2010a,b). However, the increases in milk fat CLA content in response to a combination of plant oils and marine lipids have often been accompanied by alterations in ruminal biohydrogenation $(\mathbf{B H})$ pathways, leading to a shift toward the formation of trans-10 18:1 at the expense of trans-11 18:1 and a decrease in milk fat synthesis in cattle (Shingfield et al., 2006; Invernizzi et al., 2010) and sheep (Toral et al., 2010a,b). Nevertheless, relatively few studies have characterized the effect of plant oils and marine lipids in the diet on the abundance of specific FA in ruminal digesta (AbuGhazaleh et al., 2002; Toral et al., 2010c).

Traditional culture-based methods for studying the effects of diet composition on ruminal bacteria and protozoa are less sensitive and accurate compared with molecular microbial methods based on 16S/18S rRNA genes. Use of culture-independent techniques have shown that alterations in the formation of specific $\mathrm{BH}$ intermediates to fish oil (Kim et al., 2008; Huws et al., 2010; Liu et al., in press) or marine algae (Boeckaert et al., 2007, 2008) in the diet may involve changes in specific populations of ruminal bacteria and protozoa in cattle. However, investigations of the effect of lipid supplements on the abundance of microorganisms involved in ruminal BH in sheep are limited (Boeckaert et al., 2009; Belenguer et al., 2010). 
Previous investigations indicated that changes in the FA composition of rumen fluid in nonlactating sheep fed diets containing fish oil and sunflower oil (SO, Helianthus annus; Toral et al., 2010c) did not provide a complete explanation for the effects of these lipid supplements on milk production and milk fat composition in lactating sheep (Toral et al., 2010a). Analysis of ruminal microbial communities using terminal RFLP (T-RFLP) also revealed that fish oil and SO induced comparable changes in certain groups of bacteria belonging to the family Lachnospiraceae or to the clostridial cluster IX in lactating and nonlactating sheep, whereas the effect on other groups possibly involved in ruminal BH differed (Belenguer et al., 2010).

The objective of this study was therefore to examine and characterize the changes in the bacterial ecology and appearance of biohydrogenation intermediates in the rumen of sheep fed diets that alter milk FA composition and inhibit mammary lipogenesis.

\section{MATERIALS AND METHODS}

\section{Animals, Diets, and Experimental Design}

All experimental procedures were performed in accordance with the Spanish Royal Decree 1201/2005 for the protection of animals used for experimental and other scientific purposes. Twenty-five lactating Assaf ewes of mean parity $3.7 \pm 0.10, \mathrm{BW} 85 \pm 1.7 \mathrm{~kg}$, and $97 \pm 1.0$ DIM producing $2.27 \pm 0.101 \mathrm{~kg}$ of milk/d were used. Ewes were allocated at random to 5 experimental treatments (5 animals/treatment): containing no additional lipid supplements (control diet) or supplemented with $25 \mathrm{~g}$ of $\mathrm{SO}$ and $0,8,16$, or $24 \mathrm{~g}$ of MA/ $\mathrm{kg}$ of diet DM (SO, SOMA $1, \mathbf{S O M A}_{2}$, and $\mathbf{S O M A}_{3}$ diets, respectively). Experimental diets were composed of dehydrated alfalfa hay (Medicago sativa) and concentrates (forage:concentrate ratio 485:515) and fed as TMR to minimizing the sorting of dietary components. Sunflower oil (Carrefour, S.A., Madrid, Spain) and MA (DHA Gold Animal Feed Ingredient, Martek Biosciences Corp., Columbia, MD) replaced other dietary ingredients on a proportional basis. Dietary ingredients and chemical composition of experimental diets are shown in Table 1.

The experiment lasted $4 \mathrm{wk}$ and rations were prepared weekly and offered ad libitum twice daily at 0900 and $1900 \mathrm{~h}$. Ewes were housed in tie stalls and had continuous access to fresh water. Effects of treatments on intake, milk production, and milk FA composition have been reported elsewhere (Toral et al., 2010b).

Table 1. Ingredients and chemical composition $(\mathrm{g} / \mathrm{kg}$ of $\mathrm{DM})$ of the experimental $\operatorname{dits}^{1}$

\begin{tabular}{|c|c|c|c|c|c|}
\hline Item & Control & SO & $\mathrm{SOMA}_{1}$ & $\mathrm{SOMA}_{2}$ & $\mathrm{SOMA}_{3}$ \\
\hline \multicolumn{6}{|c|}{ Ingredients ( $\mathrm{g} / \mathrm{kg}$ of fresh matter) } \\
\hline Dehydrated alfalfa hay & 484 & 474 & 470 & 466 & 462 \\
\hline Whole corn grain & 136 & 133 & 131 & 130 & 129 \\
\hline Whole barley grain & 175 & 170 & 169 & 168 & 167 \\
\hline Soybean meal & 97 & 95 & 94 & 93 & 92 \\
\hline Beet pulp & 49 & 47 & 47 & 47 & 46 \\
\hline Molasses & 37 & 36 & 36 & 36 & 36 \\
\hline Feed supplement ${ }^{2}$ & 22 & 21 & 21 & 21 & 21 \\
\hline Sunflower oil ${ }^{3}$ & 0 & 24 & 24 & 24 & 24 \\
\hline Marine algae $^{4}$ & 0 & 0 & 8 & 15 & 23 \\
\hline \multicolumn{6}{|c|}{ Chemical composition (g/kg of DM) } \\
\hline $\mathrm{OM}$ & 896 & 900 & 897 & 893 & 899 \\
\hline $\mathrm{CP}$ & 161 & 159 & 158 & 159 & 158 \\
\hline $\mathrm{NDF}$ & 308 & 304 & 296 & 300 & 293 \\
\hline $\mathrm{ADF}$ & 198 & 195 & 190 & 191 & 187 \\
\hline Ether extract & 26 & 50 & 54 & 57 & 63 \\
\hline
\end{tabular}

${ }^{1}$ Refers to TMR based on dehydrated alfalfa hay and concentrates containing no additional lipid (control), or supplemented with $25 \mathrm{~g}$ of sunflower oil and $0(\mathrm{SO}), 8\left(\mathrm{SOMA}_{1}\right), 16\left(\mathrm{SOMA}_{2}\right)$, or $24\left(\mathrm{SOMA}_{3}\right) \mathrm{g}$ of marine algae $/ \mathrm{kg}$ of diet DM.

${ }^{2}$ Contained $(\mathrm{g} / \mathrm{kg}) \mathrm{NaHCO}_{3}(333), \mathrm{CaCO}_{3}(311), \mathrm{Ca}_{2} \mathrm{HPO}_{4}$ (133), mine salt (111), and mineral and vitamins (111; INA OV1, Evialis, Madrid, Spain).

${ }^{3}$ Contained (g/kg) 16:0 (52.7), 18:0 (42.1), cis-9 18:1 (347), cis-11 18:1 (7.7), 18:2n-6 (479), 20:0 (2.7), cis-11 20:1 (1.6), 22:0 (7.1), 24:0 (2.2), other (11), and total fatty acids (953).

${ }^{4}$ DHA Gold Animal Feed Ingredient (Martek Biosciences Corp., Columbia, MD), contained (g/kg of DM) OM (913), CP (103), and ether extract (403). Fatty acid composition (g/kg of lipid): 12:0 (2.9), 14:0 (99.3), 14:2n-3 (1.5) 15:0 (4.2), 16:0 (245), cis-9 16:1 (1.6), 16:2n-3 (1.2), 16:3n-3 (1.5), 18:0 (5.8), cis-11 18:1 (1.2), 18:3n-6 (2.1), 18:4n-3 (3.0), 20:0 (1.5), 20:3n-6 (3.7), 20:4n-3 (8.1), 20:4n-5 (1.6), 20:4n-6 (4.7), 20:4n-7 (12.5), 20:5n-3 (14.0), 22:4n-9 (2.8), 22:5n-3 (3.6), 22:5n-6 (147), 22:6n-3 (369), 26:0 (3.9), other (18.3), unidentified (5.6), and total fatty acids (955). 


\section{Rumen Sample Collection}

On d 29 of the experiment, ewes were given free access to morning rations for $3 \mathrm{~h}$. Thereafter, feeds were removed and $3 \mathrm{~h}$ later samples of rumen fluid were collected from each ewe using a stomach tube. Immediately after collection, subsamples (approximately 50 $\mathrm{mL}$ ) of rumen fluid were frozen at $-80^{\circ} \mathrm{C}$, freeze-dried, and stored at $-80^{\circ} \mathrm{C}$ until analysis.

\section{FA Analysis}

Fatty acid methyl esters (FAME) of lipid in SO and MA were prepared in a 1-step extraction-transesterification procedure (Shingfield et al., 2003). Lipid in $200 \mathrm{mg}$ of freeze-dried rumen fluid was extracted and converted to FAME by base-acid catalyzed transesterification (Toral et al., 2010c). Methyl esters were quantified by GC using a temperature gradient program (Shingfield et al., 2003) and isomers of 18:1 and 18:2 were further resolved in a separate analysis under isothermal conditions (Shingfield et al., 2003). Peaks were routinely identified using a mixture of authentic standards and retention time comparisons with samples of rumen digesta collected from sheep fed fish oil and SO (Toral et al., 2010c) and omasal digesta from cows fed fish oil (Kairenius et al., 2011), for which the FA composition was determined based on GC analysis of FAME and GC-MS analysis of corresponding 4,4-dimethyloxazoline derivatives. The distribution of CLA isomers in rumen fluid was determined by $\mathrm{Ag}+-\mathrm{HPLC}$ (Shingfield et al., 2003).

\section{Microbial Community Analysis}

After thorough mixing, DNA was extracted from samples of freeze-dried rumen fluid (Belenguer et al., 2010). Duplicates were combined and used as templates for quantitative real-time PCR (qPCR) amplification and T-RFLP analysis. Sample DNA concentration was determined by spectrophotometry (NanoDrop ND-1000 Spectrophotometer, Nanodrop Technologies, Wilmington, DE).

The qPCR analysis was carried out using the Applied Biosystems StepOne Plus Real Time PCR system (Applied Biosystems, Foster City, CA) to investigate the abundance of Butyrivibrio capable of producing trans-11 18:1 and 18:0. The 16S rRNA gene-targeted primer sets included those for total bacteria (Maeda et al., 2003) and Butyrivibrio spp. that produce trans-11 18:1 (R. J. Wallace, Rowett Institute of Nutrition and Health, Aberdeen, UK, personal communication) and 18:0 (molecular beacon approach; Paillard et al., 2007). All procedures were performed as outlined previously (Belenguer et al., 2010).
Two different T-RFLP analyses were performed. The first used a universal bacteria-specific primer pair set (Hongoh et al., 2003) and 3 restriction enzymes (HhaI, $M s p I$, and HaeIII) for total bacteria analysis. The second analysis was based on Butyrivibrio group-specific primers (Boeckaert et al., 2008) and 1 restriction enzyme (HhaI; Belenguer et al., 2010). The lengths of the fluorescently labeled terminal restriction fragments (T-RF) were determined by using the size standard ET-550-R (GE Healthcare Life Sciences, Buckinghamshire, UK) using the GeneMarker Analysis software (SoftGenetics, State College, PA).

Sample data (size, bp, and peak area for each T-RF) were analyzed as outlined by Castillo et al. (2007) and used to determine the number of T-RF (richness) and the Shannon-Wiener and Shannon evenness indices (Hill et al., 2003). In silico restriction for the major rumen bacteria with the primers and enzymes used in the analysis, obtained from the Ribosomal Database Project II Web site (http://rdp.cme.msu.edu/index. jsp; Cole et al., 2009), was used to infer the potential bacterial composition of rumen fluid.

\section{Statistical Analysis}

Data from FA composition of rumen fluid and qPCR and the relative frequencies of the T-RF were analyzed by 1-way ANOVA, using the MIXED procedure of the SAS software package, version 9.1 (SAS Inst. Inc., Cary, NC). Because some qPCR results did not satisfy the assumptions of data normality, data were transformed to $\log _{10}$ before ANOVA. The statistical model included the fixed effect of treatment and random effect of animal. Means were separated using the "pdiff" option of the "Ismeans" statement of the MIXED procedure. In addition, linear and quadratic components of the response to incremental amounts of MA in the diet were evaluated using orthogonal polynomial contrasts. Least squares means are reported and treatment effects were declared significant at $P<0.05$ and considered a trend toward significance at $P<0.10$.

The matrix with the T-RFLP data obtained by the 3 single-enzyme digestions for the total bacteria and by the HhaI digestion for the Butyrivibrio group was analyzed using hierarchical clustering with the Ward's method based on Jaccard distances (1 - Jaccard coefficient) with the Community Analysis Package 4 software (Pisces Conservation Ltd., Lymington, UK).

\section{RESULTS}

\section{FA Composition of Rumen Fluid}

Dietary supplements of SO did not affect the proportion of total saturated FA in rumen fluid, whereas the 
inclusion of MA resulted in a substantial decrease (63.7 vs. $32.7 \%$ of total FA for Control and SOMA, respectively $(P<0.001)$; data not reported). Compared with the control, the concentration of 18:0 was marginally increased $(+16 \%)$ on the SO treatment but was, on average, $88 \%$ lower in ewes fed diets containing MA ( $P$ $<0.001$; Table 2). Dietary SO alone or in combination with MA lowered the proportions of 16:0 and 2 minor saturated FA, 20:0 and 28:0, in the rumen $(P<0.05)$ and increased that of 22:0 $(P<0.05)$. Inclusion of MA in the diet also linearly increased 14:0 concentrations $(P<0.001)$.

Concentrations of oxygenated 18-carbon FA (9-, 10-, 13-, and 15-O-18:0) were low in the digesta of ewes fed control and SO treatments, whereas the inclusion of MA resulted in a quadratic increase in ruminal 10-O18:0 concentrations $(P<0.001$; Table 2$)$. In contrast, the abundance of total odd- and branched-chain FA in the rumen of ewes fed diets containing lipid supplements was decreased $(-34 \%, P<0.001$; data not presented), because of lower concentrations of most 15- to 19-carbon odd- and branched-chain FA $(P<0.05)$.

Experimental treatments resulted in isomer-dependent changes in the relative abundance of 16-carbon FA in rumen fluid (Table 3). All lipid supplements decreased ruminal cis-9 16:1 concentrations, whereas MA quadratically increased trans 16:1 concentrations $(P<0.001)$.

For all treatments, trans-11 was the most abundant 18:1 isomer (Table 3). With the exception of trans-10 and trans-11 18:1, concentrations of trans- 4 to trans- 15 18:1 were greater for $\mathrm{SOMA}_{1}$ compared with other treatments $(P<0.001)$. In contrast, ruminal trans-10 18:1 concentrations were greater for $\mathrm{SOMA}_{2}$ compared with the control, $\mathrm{SO}$, or $\mathrm{SOMA}_{1}$ treatments, whereas the abundance for $\mathrm{SOMA}_{3}$ was intermediate relative to $\mathrm{SOMA}_{1}$ and $\mathrm{SOMA}_{2}(P<0.01)$. Supplementing the diet with SO increased ruminal cis-12 18:1 concentrations $(P<0.001)$, whereas MA had divergent effects on cis 18:1 isomer concentrations (Table 3 ).

Sunflower oil in the diet had no effect on 18:2 isomers in rumen fluid, other than a decrease in cis-9,cis-12 18:2 and an increase in cis-11,cis-14 18:2 concentrations $(P$ $<0.001$; Table 4). However, inclusion of SOMA in the diet increased $(P<0.001)$ the relative abundance of most 18:2 nonconjugated isomers in rumen fluid (Table 4). Concentrations of the major CLA isomer in rumen fluid, cis-9,trans-11, were increased on $\mathrm{SOMA}_{1}(P<$ 0.01 ), whereas treatments had relatively minor effects on the abundance of other CLA isomers.

As expected, SO in the diet had no substantial effect on the abundance of 20- and 22-carbon unsaturated FA in rumen fluid (Table 5). Because MA contained small amounts of 20-carbon FA, the changes in their relative proportion in the rumen fluid to SOMA treatments were marginal compared with the control and SO diets. Furthermore, little variation in the low concentration of 22:1 intermediates was observed in response to MA in the diet. However, incremental amounts of MA resulted in dose-dependent increases in most 22-carbon PUFA, changes that were highly significant due to the low abundance of these FA in rumen fluid of ewes fed the control and SO treatments. Ruminal concentrations of 22:5n-6 and 22:6n-3 increased linearly $(P<0.001)$ in response to graded amounts of MA in the diet, changes that were also accompanied by the appearance of unique 22-carbon intermediates in rumen fluid including $\Delta 10,13,17 \quad 22: 3$, cis-7,trans-13,cis-16,cis-19 22:4, and trans-5,cis-10,cis-13,cis-16,cis-19 22:5. No 22-carbon FA containing a conjugated double bond or unique 22:6 isomers were detected in rumen fluid of sheep fed $\mathrm{SO}$ and MA.

\section{Bacterial Community Analysis by T-RFLP}

Rumen bacterial T-RFLP analysis generated on average $32.9 \pm 1.10,54.7 \pm 1.57$, and $67.6 \pm 4.58$ fragments with the enzymes HhaI, MspI, and HaeIII, respectively, with substantial variation between animals. Hierarchical clustering analysis grouped the bacterial community structures according to dietary treatments (Figure 1a), resulting in 2 major clusters, with most samples obtained from animals fed the control or SO diet being grouped together and separate from those collected from ewes fed diets containing MA. Samples of the SO treatment formed a subgroup within the first cluster, and most samples from ewes on $\mathrm{SOMA}_{1}$ grouped together and segregated from samples of $\mathrm{SOMA}_{2}$ and $\mathrm{SOMA}_{3}$ (Figure 1a).

The diversity indices were similar for all treatments after HhaI and HaeIII digestions (Table 6). However, according to the Shannon-Wiener index, the $M s p I$ digestion indicated greater diversity of ruminal bacteria for $\mathrm{SO}$ and $\mathrm{SOMA}_{1}$ compared with $\mathrm{SOMA}_{2}$ and $\mathrm{SOMA}_{3}$.

Several different T-RF exhibited variations in their relative frequency out of the total peak area due to treatments. The relative frequency of T-RF compatible with Quinella-related bacteria increased in a linear (150 plus 268 bp with $M s p I$, and 244 plus 288 bp with HaeIII) or quadratic (98 bp with HhaI) manner with incremental amounts of MA in the diet (Table 7), although these fragments exhibited considerable variation between animals. Certain $\mathrm{T}-\mathrm{RF}$ that may correspond to uncultured bacteria belonging to the subphylum Clostridia (380, 217, and 309 bp with HhaI, $M s p I$, and HaeIII, respectively) were detected in lower relative proportions $(P<0.05)$ in samples from ewes fed MA than on the SO or control diet. In contrast, 
Table 2. Effect of diet supplementation with sunflower oil alone or in combination with incremental amounts of marine algae on FA composition of rumen fluid in lactating ewes

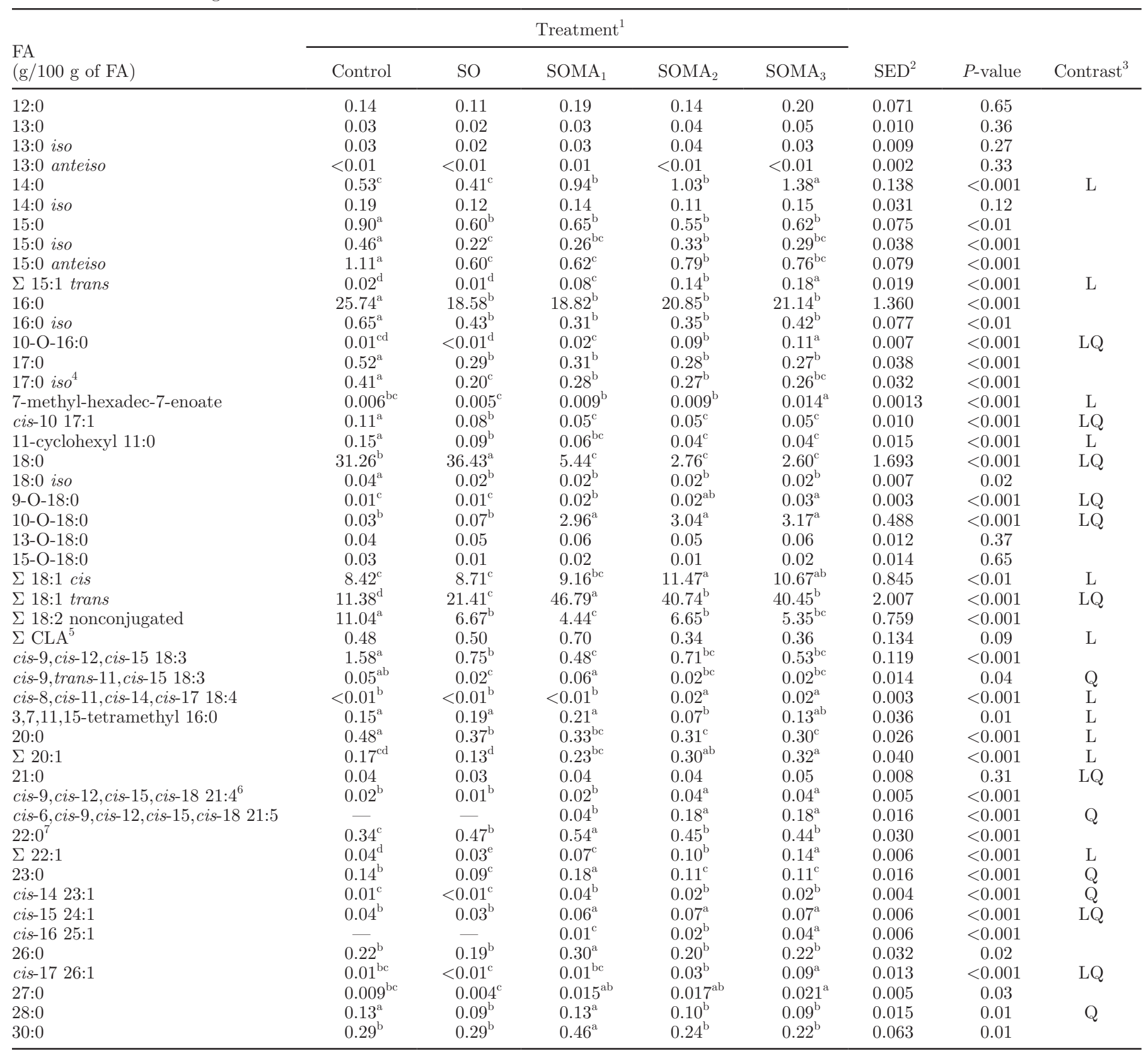

${ }^{\mathrm{a}-\mathrm{e}}$ Within a row, different superscripts indicate significant differences $(P<0.05)$.

${ }^{1}$ Refers to TMR based on dehydrated alfalfa hay and concentrates containing no additional lipid (control), or supplemented with $25 \mathrm{~g}$ of sunflower oil and $0(\mathrm{SO}), 8\left(\mathrm{SOMA}_{1}\right), 16\left(\mathrm{SOMA}_{2}\right)$, or $24\left(\mathrm{SOMA}_{3}\right) \mathrm{g}$ of marine algae $(\mathrm{MA}) / \mathrm{kg}$ of diet DM.

${ }^{2} \mathrm{SED}=$ standard error of the difference.

${ }^{3}$ Indicates significant $(P<0.05)$ linear $(\mathrm{L})$ or quadratic $(\mathrm{Q})$ components of the response to incremental MA supplementation of a TMR containing sunflower oil estimated by orthogonal polynomial contrasts using data for $\mathrm{SO}, \mathrm{SOMA}_{1}, \mathrm{SOMA}_{2}$, and $\mathrm{SOMA}_{3}$ treatments.

${ }^{4}$ Coelutes with trans-9 16:1.

${ }^{5} \mathrm{CLA}=$ conjugated linoleic acid.

${ }^{6}$ Coelutes with 24:1.

${ }^{7}$ Coelutes with trans-10,trans-14,trans-17 20:3. 
Table 3. Effect of diet supplementation with sunflower oil alone or in combination with incremental amounts of marine algae on 16:1 and 18:1 isomer concentrations of rumen fluid in lactating ewes

\begin{tabular}{|c|c|c|c|c|c|c|c|c|}
\hline $\begin{array}{l}\text { Isomer } \\
(\mathrm{g} / 100 \mathrm{~g} \text { of } \mathrm{FA})\end{array}$ & \multicolumn{5}{|c|}{ Treatment $^{1}$} & $\mathrm{SED}^{2}$ & $P$-value & Contrast $^{3}$ \\
\hline cis-9 $16: 1^{4}$ & $0.85^{\mathrm{a}}$ & $0.51^{\mathrm{b}}$ & $0.56^{\mathrm{b}}$ & $0.56^{\mathrm{b}}$ & $0.62^{\mathrm{b}}$ & 0.053 & $<0.001$ & \\
\hline cis-11 16:1 & $0.03^{\mathrm{a}}$ & $0.01^{\mathrm{b}}$ & $0.01^{\mathrm{b}}$ & $<0.01^{\mathrm{b}}$ & $0.01^{\mathrm{b}}$ & 0.002 & $<0.001$ & \\
\hline cis-13 16:1 & $0.006^{\mathrm{b}}$ & $0.005^{\mathrm{b}}$ & $0.013^{\mathrm{a}}$ & $0.006^{\mathrm{b}}$ & $0.007^{\mathrm{b}}$ & 0.0013 & $<0.001$ & $\mathrm{Q}$ \\
\hline trans-5 16:1 & - & - & $0.009^{\mathrm{a}}$ & $0.007^{\mathrm{b}}$ & $0.008^{\mathrm{ab}}$ & 0.0010 & $<0.001$ & LQ \\
\hline cis-9 $18: 1^{5}$ & $6.83^{\mathrm{c}}$ & $6.61^{\mathrm{c}}$ & $7.31^{\mathrm{bc}}$ & $9.90^{\mathrm{a}}$ & $8.97^{\mathrm{ab}}$ & 0.912 & $<0.01$ & $\mathrm{~L}$ \\
\hline cis-11 18:1 & $0.63^{\mathrm{b}}$ & $0.56^{\mathrm{b}}$ & $1.10^{\mathrm{a}}$ & $0.98^{\mathrm{a}}$ & $1.07^{\mathrm{a}}$ & 0.125 & $<0.001$ & LQ \\
\hline cis-12 18:1 & $0.54^{\mathrm{b}}$ & $1.14^{\mathrm{a}}$ & $0.25^{\mathrm{c}}$ & $0.18^{\mathrm{c}}$ & $0.23^{\mathrm{c}}$ & 0.062 & $<0.001$ & LQ \\
\hline cis-13 18:1 & $0.12^{\mathrm{bc}}$ & $0.08^{\mathrm{c}}$ & $0.15^{\mathrm{ab}}$ & $0.12^{\mathrm{bc}}$ & $0.18^{\mathrm{a}}$ & 0.023 & $<0.01$ & $\mathrm{~L}$ \\
\hline cis-15 $18: 1^{6}$ & 0.17 & 0.16 & 0.21 & 0.20 & 0.17 & 0.024 & 0.12 & \\
\hline cis-16 18:1 & $0.13^{\mathrm{a}}$ & $0.15^{\mathrm{a}}$ & $0.14^{\mathrm{a}}$ & $0.07^{\mathrm{b}}$ & $0.05^{\mathrm{b}}$ & 0.014 & $<0.001$ & $\mathrm{~L}$ \\
\hline trans-4 18:1 & $0.14^{\mathrm{b}}$ & $0.19^{\mathrm{b}}$ & $0.37^{\mathrm{a}}$ & $0.14^{\mathrm{b}}$ & $0.18^{\mathrm{b}}$ & 0.033 & $<0.001$ & LQ \\
\hline trans-12 18:1 & $0.73^{\mathrm{d}}$ & $1.25^{\mathrm{c}}$ & $2.32^{\mathrm{a}}$ & $1.34^{\mathrm{b}}$ & $1.29^{\mathrm{b}}$ & 0.192 & $<0.001$ & $\mathrm{Q}$ \\
\hline trans-13 18:1 & $1.38^{\mathrm{c}}$ & $2.01^{\mathrm{b}}$ & $3.28^{\mathrm{a}}$ & $1.78^{\mathrm{bc}}$ & $1.65^{\mathrm{bc}}$ & 0.293 & $<0.001$ & $\mathrm{LQ}$ \\
\hline trans-15 $18: 1^{7}$ & $0.70^{\mathrm{b}}$ & $0.94^{\mathrm{a}}$ & $1.06^{\mathrm{a}}$ & $0.73^{\mathrm{b}}$ & $0.67^{\mathrm{b}}$ & 0.085 & $<0.001$ & $\mathrm{~L}$ \\
\hline trans-16 $18: 1^{8}$ & $0.73^{\mathrm{a}}$ & $0.85^{\mathrm{a}}$ & $0.62^{\mathrm{a}}$ & $0.34^{\mathrm{b}}$ & $0.29^{\mathrm{b}}$ & 0.074 & $<0.001$ & $\mathrm{~L}$ \\
\hline
\end{tabular}

${ }^{\mathrm{a}-\mathrm{d}}$ Within a row, different superscripts indicate significant differences $(P<0.05)$.

${ }^{1}$ Refers to TMR based on dehydrated alfalfa hay and concentrates containing no additional lipid (control), or supplemented with $25 \mathrm{~g}$ of sunflower oil and $0(\mathrm{SO}), 8\left(\mathrm{SOMA}_{1}\right), 16\left(\mathrm{SOMA}_{2}\right)$, or $24\left(\mathrm{SOMA}_{3}\right) \mathrm{g}$ of marine algae $(\mathrm{MA}) / \mathrm{kg}$ of diet DM.

${ }^{2} \mathrm{SED}=$ standard error of the difference.

${ }^{3}$ Indicates significant $(P<0.05)$ linear $(\mathrm{L})$ or quadratic $(\mathrm{Q})$ components of the response to incremental MA supplementation of a TMR containing sunflower oil estimated by orthogonal polynomial contrasts using data for SO, SOMA $1, \mathrm{SOMA}_{2}$, and $\mathrm{SOMA}_{3}$ treatments.

${ }^{4}$ Coelutes with 17:0 anteiso.

${ }^{5}$ Contains trans-14 18:1 as a minor component.

${ }^{6}$ Coelutes with 19:0.

${ }^{7}$ Contains cis-10 18:1 as a minor component.

${ }^{8}$ Contains cis-14 18:1 as a minor component.

the relative abundance of some others compatible with uncultivated bacteria of the order Clostridiales (390 bp with HhaI, 227 with $M s p I$, and 276 with HaeIII) was greater $(P<0.05)$ in samples from the $\mathrm{SO}$ or $\mathrm{SOMA}_{1}$ treatments compared with the control. In addition to fragments matching with the 3 enzymes listed in Table 7, treatments also altered other T-RF. For example, a 65-bp T-RF obtained with HhaI, compatible with bacteria of the phylum Firmicutes, showed a lower relative proportion in samples on $\mathrm{SOMA}_{3}$ (data not shown).

\section{Butyrivibrio Population Analysis by T-RFLP}

Even though diversity indices did not change in response to treatments, possibly as a result of substantial between-animal variation (Table 6), most of the T-RFLP profiles of the Butyrivibrio population in samples from the control and $\mathrm{SO}$ were grouped together and separated from those from MA-containing diets (Figure 1b).
The relative frequency of the 300-bp fragment was higher in samples on $\mathrm{SOMA}_{2}$ and $\mathrm{SOMA}_{3}$ treatments compared with the control $(P<0.05$; Table 7$)$, whereas the relative proportion of the 164-bp T-RF was greater when diets contained SO alone $(P<0.01)$, but decreased in a quadratic manner $(P<0.05)$ in response to incremental amounts of MA in the diet.

\section{Microbial Population Analysis by qPCR}

Quantification of the Butyrivibrio trans-11 18:1-producing bacteria showed no significant changes in response to treatments either in their relative proportion of the total bacteria (mean $0.23 \pm 0.033 \%$ ) or when expressed on the basis of DNA concentration (mean $0.16 \pm 0.038 \mathrm{pg} / \mathrm{ng}$ of total DNA; Table 8). Inclusion of SO or MA or both in the diet had no effect on the DNA concentration of the 18:0-producing Butyrivibrio (Butyrivibrio proteoclasticus group) bacteria, whose 
Table 4. Effect of diet supplementation with sunflower oil alone or in combination with incremental amounts of marine algae on 18:2 isomer concentrations of rumen fluid in lactating ewes

\begin{tabular}{|c|c|c|c|c|c|c|c|c|}
\hline $\begin{array}{l}\text { Isomer } \\
\text { (g/100 } \mathrm{g} \text { of } \mathrm{FA})\end{array}$ & \multicolumn{5}{|c|}{ Treatment $^{1}$} & $\mathrm{SED}^{2}$ & $P$-value & Contrast \\
\hline cis-9,cis-12 18:2 & $10.65^{\mathrm{a}}$ & $6.30^{\mathrm{b}}$ & $3.50^{\mathrm{d}}$ & $5.49^{\mathrm{bc}}$ & $4.05^{\mathrm{cd}}$ & 0.755 & $<0.001$ & $\mathrm{~L}$ \\
\hline cis-11,cis-14 18:2 & $0.03^{\mathrm{b}}$ & $0.07^{\mathrm{a}}$ & $<0.01^{\mathrm{c}}$ & $<0.01^{\mathrm{c}}$ & $<0.01^{\mathrm{c}}$ & 0.005 & $<0.001$ & LQ \\
\hline cis-12,cis-15 18:2 & $0.013^{\mathrm{a}}$ & $0.012^{\mathrm{ab}}$ & $0.009^{\mathrm{bc}}$ & $0.011^{\mathrm{abc}}$ & $0.008^{\mathrm{c}}$ & 0.0019 & 0.04 & \\
\hline cis-9,trans-12 18:2 & $0.03^{\mathrm{b}}$ & $0.03^{\mathrm{b}}$ & $0.05^{\mathrm{a}}$ & $0.04^{\mathrm{a}}$ & $0.05^{\mathrm{a}}$ & 0.005 & $<0.001$ & LQ \\
\hline cis-11,trans-15 $18: 2^{4}$ & $0.01^{\mathrm{c}}$ & $0.01^{\mathrm{c}}$ & $0.05^{\mathrm{b}}$ & $0.11^{\mathrm{a}}$ & $0.09^{\mathrm{a}}$ & 0.015 & $<0.001$ & LQ \\
\hline trans-11,trans-14 18:2 $2^{5}$ & $0.03^{\mathrm{b}}$ & $0.03^{\mathrm{b}}$ & $0.04^{\mathrm{b}}$ & $0.08^{\mathrm{a}}$ & $0.11^{\mathrm{a}}$ & 0.010 & $<0.001$ & LQ \\
\hline trans-11,trans-15 18:2 & $0.02^{\mathrm{b}}$ & $0.03^{\mathrm{b}}$ & $0.08^{\mathrm{a}}$ & $0.08^{\mathrm{a}}$ & $0.11^{\mathrm{a}}$ & 0.017 & $<0.001$ & $\mathrm{~L}$ \\
\hline trans-12,cis-15 18:2 & $<0.01$ & $<0.01$ & $<0.01$ & $<0.01$ & 0.01 & 0.002 & 0.30 & \\
\hline cis-9,trans-11 CLA $^{6}$ & $0.29^{\mathrm{b}}$ & $0.33^{\mathrm{b}}$ & $0.54^{\mathrm{a}}$ & $0.18^{\mathrm{b}}$ & $0.20^{\mathrm{b}}$ & 0.092 & $<0.01$ & $\mathrm{~L}$ \\
\hline cis-12,trans-14 CLA & $<0.01$ & $<0.01$ & $<0.01$ & $<0.01$ & $<0.01$ & 0.001 & 0.35 & \\
\hline trans-7,cis-9 CLA & $<0.01$ & $<0.01$ & $<0.01$ & $<0.01$ & $<0.01$ & 0.002 & 0.24 & \\
\hline trans-8,cis-10 CLA & $<0.01$ & $<0.01$ & $<0.01$ & $<0.01$ & $<0.01$ & 0.001 & 0.42 & \\
\hline trans-10,trans-12 CLA & 0.02 & 0.04 & 0.02 & 0.03 & 0.02 & 0.008 & 0.13 & $\mathrm{~L}$ \\
\hline trans-11,trans-13 CLA & 0.03 & 0.03 & 0.02 & 0.02 & 0.02 & 0.010 & 0.69 & \\
\hline trans-12,trans-14 CLA & $<0.01$ & $<0.01$ & $<0.01$ & $<0.01$ & $<0.01$ & 0.001 & 0.58 & \\
\hline
\end{tabular}

\footnotetext{
${ }^{\mathrm{a}-\mathrm{d}}$ Within a row, different superscripts indicate significant differences $(P<0.05)$.
}

${ }^{1}$ Refers to TMR based on dehydrated alfalfa hay and concentrates containing no additional lipid (control), or supplemented with $25 \mathrm{~g}$ of sunflower oil and $0(\mathrm{SO}), 8\left(\mathrm{SOMA}_{1}\right), 16\left(\mathrm{SOMA}_{2}\right)$, or $24\left(\mathrm{SOMA}_{3}\right) \mathrm{g}$ of marine algae $(\mathrm{MA}) / \mathrm{kg}$ of diet DM.

${ }^{2} \mathrm{SED}=$ standard error of the difference.

${ }^{3}$ Indicates significant $(P<0.05)$ linear $(\mathrm{L})$ or quadratic $(\mathrm{Q})$ components of the response to incremental MA supplementation of a TMR containing sunflower oil estimated by orthogonal polynomial contrasts using data for $\mathrm{SO}, \mathrm{SOMA}_{1}, \mathrm{SOMA}_{2}$, and $\mathrm{SOMA}_{3}$ treatments.

${ }^{4}$ Contains trans-9,trans-12 18:2 as a minor component.

${ }^{5}$ Contains trans-10,trans-13 18:2 as a minor component.

${ }^{6} \mathrm{CLA}=$ conjugated linoleic acid.

abundance was always low (mean $0.45 \pm 0.071 \mathrm{pg} / \mathrm{ng}$ of total DNA) and varied substantially between animals.

\section{DISCUSSION}

Recent studies have investigated the effect of fish oil (Kim et al., 2008) or MA (Boeckaert et al., 2008) in the diet on ruminal lipid metabolism and microbial ecology in cattle, but no reports exist for lactating sheep. Because ruminal cannulation is not feasible in lactating ewes, rumen fluid was collected via stomach tube after $28 \mathrm{~d}$ on diet, a period long enough to allow the effects of $\mathrm{SO}$ and $\mathrm{MA}$ in the diet on milk fat composition and animal performance to be determined (Toral et al., 2010b).

Changes in the relative abundance of FA in rumen fluid to SO and SOMA are consistent with the effects of 18:2n-6 rich plant oils (Atkinson et al., 2006) and fish oil (Chikunya et al., 2004; Sinclair et al., 2005) on the flow of FA at the duodenum in sheep.

Decreases in 18:0 concentrations as percentage of total long-chain FA $(\geq 18$-carbon FA) on the SOMA treatments were 3 -fold greater in rumen fluid compared with milk fat in the same ewes (Toral et al., 2010b), despite the desaturation of 18:0 to cis-9 18:1 in the mammary gland. These findings could be interpreted as evidence of compensatory mechanisms operating in the mammary gland in response to decreases in 18:0 availability that may be important in the overall regulation of milk fat fluidity and lipogenesis in ruminants (Shingfield et al., 2010a).

Relative abundance of a T-RF compatible with uncultured bacteria of the family Lachnospiraceae (Boeckaert et al., 2009), which clustered within the 18:0-producing branch, increased with $\mathrm{SO}$ and was decreased in samples of rumen fluid of ewes fed MA-containing diets. However, rumen liquid-associated bacteria are thought to have only a minor role in 18:0 formation (Boeckaert et al., 2009). Moreover, the B. proteoclasticus group, the only culturable ruminal species known to convert trans-11 18:1 or trans-10 18:1 to 18:0 (Lourenço et al., 2010; McKain et al., 2010) was neither abundant nor altered by SO or SOMA treatment relative to the control, consistent with the hypothesis that these bacteria 
Table 5. Effect of diet supplementation with sunflower oil alone or in combination with incremental amounts of marine algae on 20- and 22-carbon unsaturated FA concentrations of rumen fluid in lactating ewes

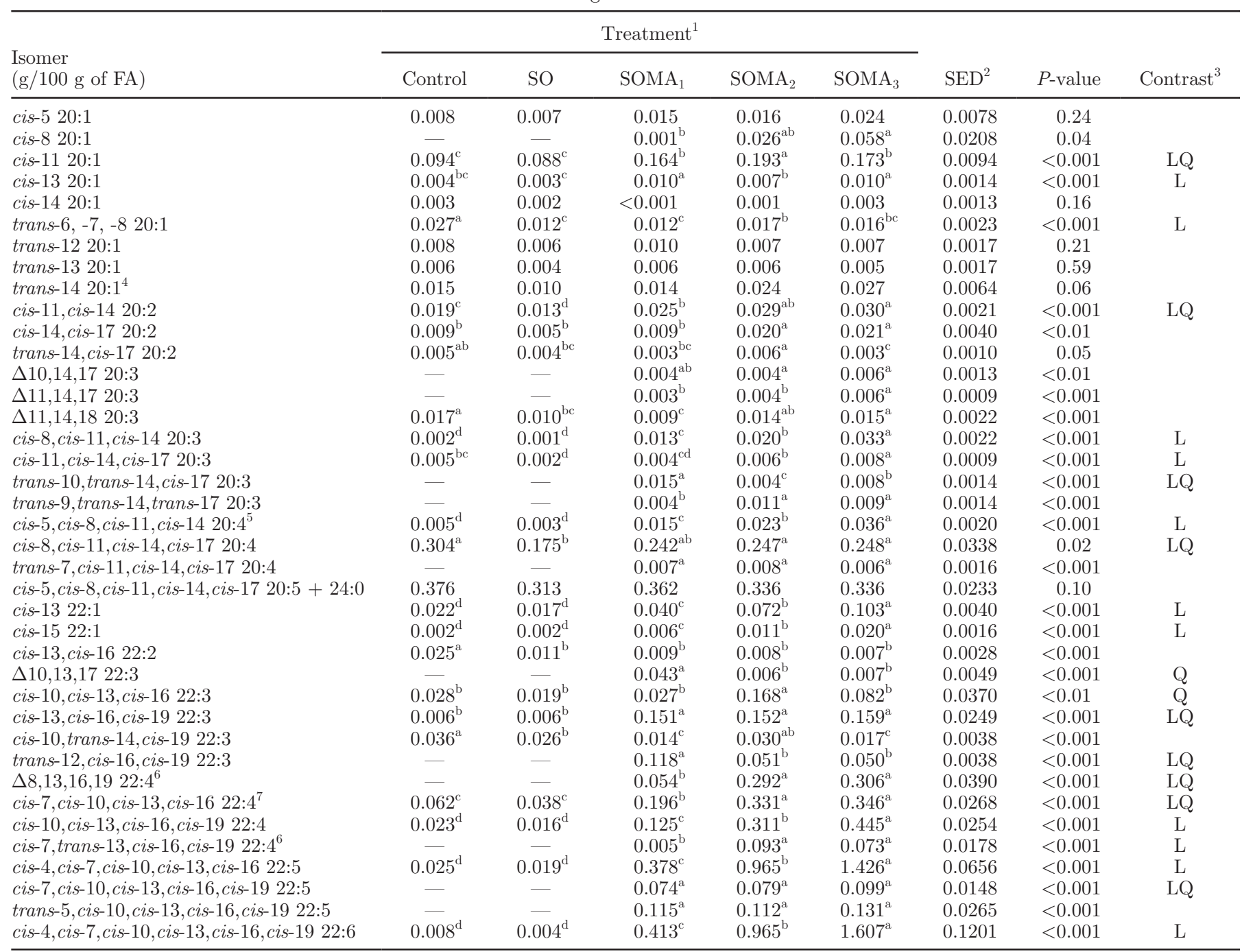

${ }^{\mathrm{a}-\mathrm{e}}$ Within a row, different superscripts indicate significant differences $(P<0.05)$.

${ }^{1}$ Refers to TMR based on dehydrated alfalfa hay and concentrates containing no additional lipid (control), or supplemented with $25 \mathrm{~g}$ of sunflower oil and $0(\mathrm{SO}), 8\left(\mathrm{SOMA}_{1}\right), 16\left(\mathrm{SOMA}_{2}\right)$, or $24\left(\mathrm{SOMA}_{3}\right) \mathrm{g}$ of marine algae $(\mathrm{MA}) / \mathrm{kg}$ of diet DM.

${ }^{2} \mathrm{SED}=$ standard error of the difference.

${ }^{3}$ Indicates significant $(P<0.05)$ linear $(\mathrm{L})$ or quadratic $(\mathrm{Q})$ components of the response to incremental MA supplementation of a TMR containing sunflower oil estimated by orthogonal polynomial contrasts using data for SO, $\mathrm{SOMA}_{1}, \mathrm{SOMA}_{2}$, and $\mathrm{SOMA}_{3}$ treatments.

${ }^{4}$ Contains cis-9 20:1 as a minor component.

${ }^{5}$ Contains cis-16 22:1 as a minor component.

${ }^{6}$ Eluted before cis-10,cis-13,cis-16,cis-19 22:4 during GC analysis.

${ }^{7}$ Coelutes with 25:0.

may not play a major role in 18:0 formation in the rumen (Boeckaert et al., 2009; Belenguer et al., 2010; Huws et al., 2010, 2011).

Despite a relatively high abundance of 16:0 in MA (25.6\% of total FA), decreases in ruminal 16:0 concentrations were comparable for SO and SOMA treatments, which can be explained, at least in part, by the relatively high variance between animals. However, current data are based on measurements of the relative proportions of FA, and therefore such changes may simply be a reflection of the increase in the total lipid content in the rumen.

The decrease in odd- and branched-chain FA abundance in rumen fluid to $\mathrm{SO}$ alone or in combination with MA, relative to the control, was in agreement with the changes reported in samples collected from 
a)

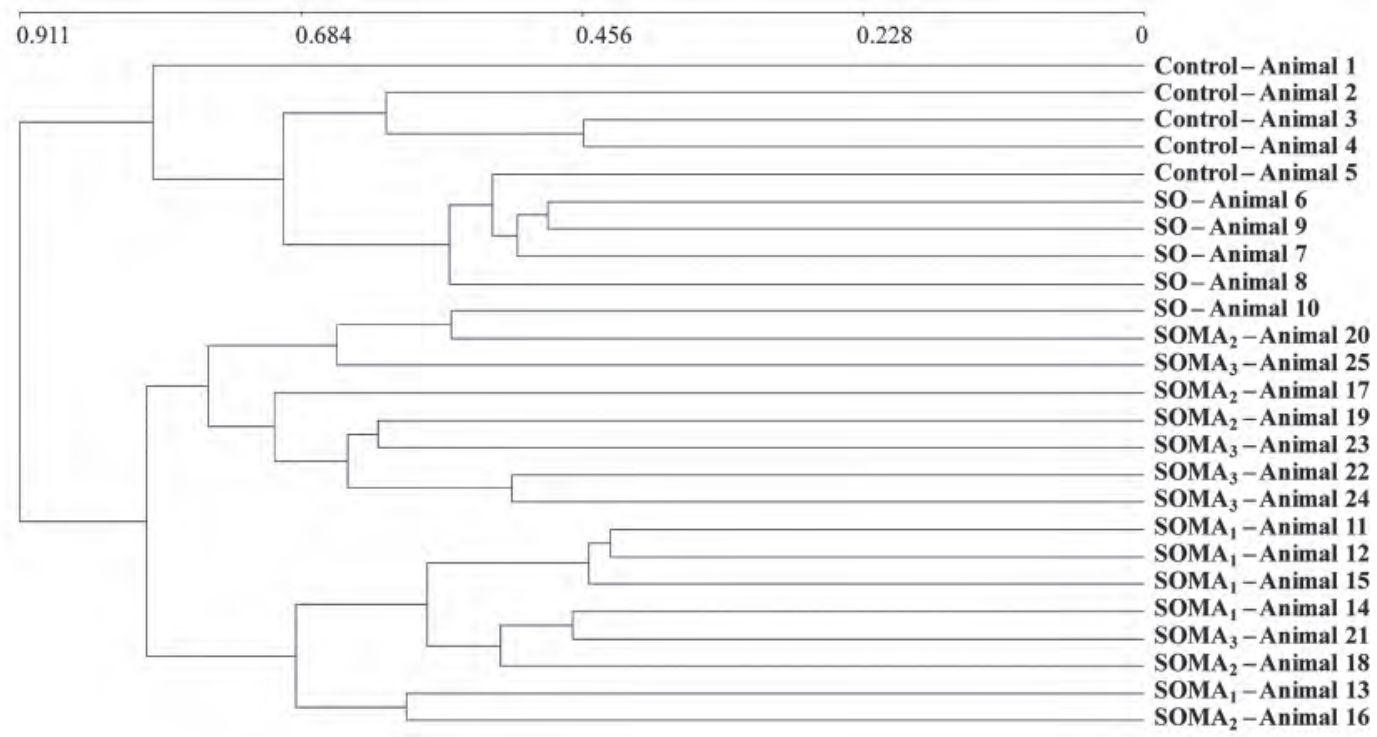

b)

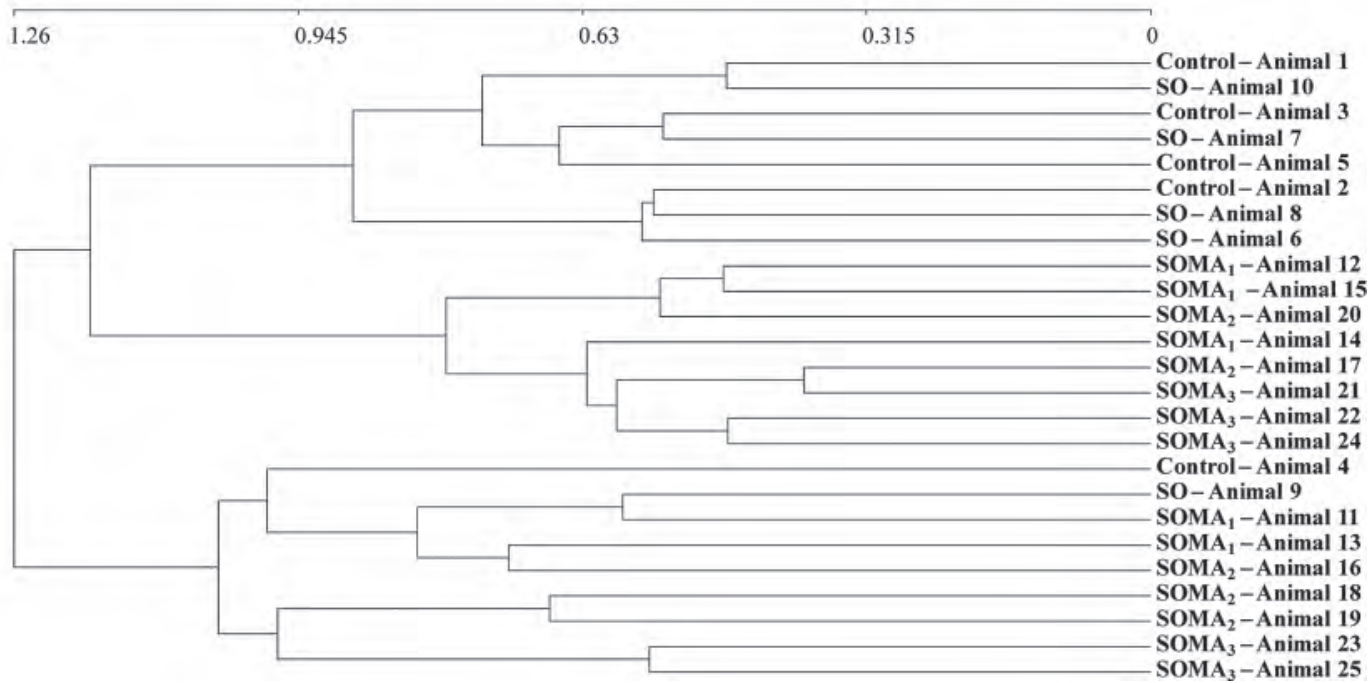

Figure 1. Terminal RFLP-derived Ward's method with Jaccard distance dendrograms showing the effect on total bacteria (a) and Butyrivibrio population (b) in DNA extracted from the rumen fluid of lactating ewes fed diets containing no additional lipid (control), sunflower oil alone (SO) or in combination with 8,16 , or $24 \mathrm{~g}$ of marine algae $/ \mathrm{kg}$ of diet $\mathrm{DM}\left(\mathrm{SOMA}_{1}, \mathrm{SOMA}_{2}\right.$, and $\mathrm{SOMA}_{3}$, respectively).

nonlactating sheep fed diets containing SO and fish oil (Toral et al., 2010c). Lipids in the diet are known to inhibit bacterial lipid synthesis de novo (Schmidely et al., 2008). In cattle, MA in the diet has been reported to decrease (Boeckaert et al., 2007), have no effect (OrRashid et al., 2008), or increase (Boeckaert et al., 2008) concentrations of ruminal odd- and branched-chain FA.

An increase of 10-O-18:0 in rumen fluid of ewes fed MA is consistent with the effects reported for fish oil in combination with SO (Toral et al., 2010c) in sheep, whereas earlier studies reported that fish oil in the diet promoted the accumulation of 10-OH-18:0 (Kitessa et al., 2001). Evidence exists that ruminal bacteria, such as Selenomonas ruminantium (Hudson et al., 1995), are capable of hydrating cis-9 18:1 or trans-10 18:1 to 10-OH-18:0, and others, including Propionibacterium acnes (McKain et al., 2010), can further oxidize 10OH-18:0 to 10-O-18:0. 
Table 6. Effect of diet supplementation with sunflower oil alone or in combination with incremental amounts of marine algae on diversity indices (richness, R; Shannon-Wiener, H; and Shannon evenness, E) calculated from the total bacteria and the Butyrivibrio group-specific terminal RFLP profiles of rumen fluid in lactating ewes

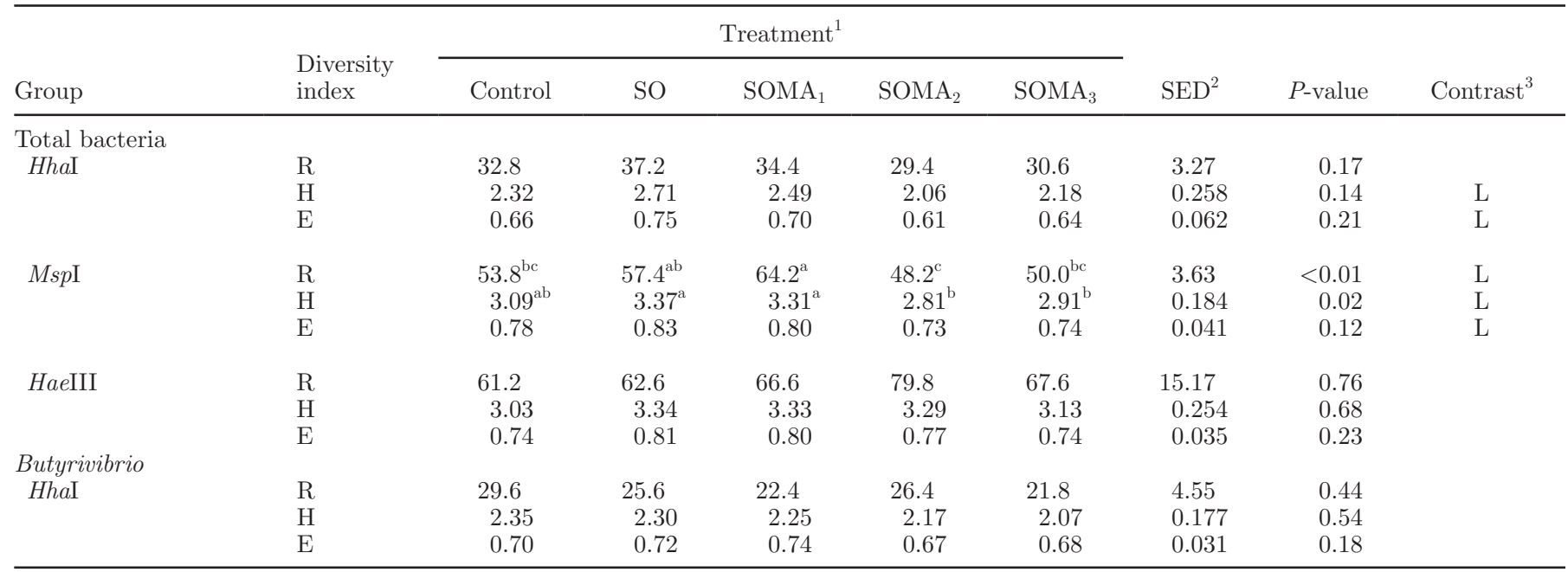

\footnotetext{
${ }^{\mathrm{a}-\mathrm{c}}$ Within a row, different superscripts indicate significant differences $(P<0.05)$.

${ }^{1}$ Refers to TMR based on dehydrated alfalfa hay and concentrates containing no additional lipid (control), or supplemented with $25 \mathrm{~g}$ of sunflower oil and $0(\mathrm{SO}), 8\left(\mathrm{SOMA}_{1}\right), 16\left(\mathrm{SOMA}_{2}\right)$, or $24\left(\mathrm{SOMA}_{3}\right) \mathrm{g}$ of marine algae $(\mathrm{MA}) / \mathrm{kg}$ of diet DM.

${ }^{2} \mathrm{SED}=$ standard error of the difference.

${ }^{3}$ Indicates significant $(P<0.05)$ linear $(\mathrm{L})$ components of the response to incremental MA supplementation of a TMR containing sunflower oil estimated by orthogonal polynomial contrasts using data for $\mathrm{SO}, \mathrm{SOMA}_{1}, \mathrm{SOMA}_{2}$, and $\mathrm{SOMA}_{3}$ treatments.
}

Rumen fluid of sheep fed diets supplemented with MA had a greater relative abundance of T-RF compatible with bacteria identified in the rumen (Yang et al., 2010) that are phylogenetically related to Quinella ovalis, and may have a metabolism similar to that of S. ruminantium (Krumholz et al., 1993). Recent studies have also reported an increase in comparable $\mathrm{T}-\mathrm{RF}$ in sheep fed diets containing SO and fish oil (Belenguer et al., 2010).

On certain diets, the addition of fish oil (Loor et al., 2005) or MA (Boeckaert et al., 2008; Or-Rashid et al., 2008) has been shown to promote a shift in ruminal $\mathrm{BH}$ toward increased formation of trans-10 18:1 at the expense of trans-11 18:1. The results from a recent study suggest that, in high amounts, trans-10 18:1 may inhibit mammary lipogenesis in the bovine (Shingfield et al., 2010a). Therefore, identifying the mechanisms underlying the shift in ruminal $\mathrm{BH}$ promoting trans-10 $18: 1$ formation in the rumen is an important component in developing a more complete understanding of the role of diet and lipid supplements on milk fat synthesis. Inclusion of SO and fish oil in the diet did not stimulate a major change in the ratio of trans-10 18:1 to trans-11 18:1 in rumen fluid of nonlactating sheep after $11 \mathrm{~d}$ on diet (Toral et al., 2010c), whereas a combination of SO and fish oil or MA over a 28-d period in lactating sheep resulted in a substantial increase in the relative proportion of trans-10 18:1 in milk (Toral et al., 2010a,b). In the present study, the ratio of trans-10 18:1 to trans-11 18:1 in rumen fluid was increased on the $\mathrm{SOMA}_{2}$ and $\mathrm{SOMA}_{3}$ diets, which may be attributable to greater amounts of 22-carbon PUFA from MA supplements in the rumen inhibiting the growth of certain trans-11 18:1-producing bacteria. However, qPCR quantification did not support a major effect of dietary treatments on known Butyrivibrio trans-11 18:1-producing bacteria, consistent with earlier investigations in sheep (Belenguer et al., 2010).

The ruminal bacteria involved in trans-10 18:1 formation during isomerization of cis-9 18:1 or as an intermediate of 18-carbon PUFA biohydrogenation remain unclear (Jenkins et al., 2008; McKain et al., 2010). To date, only a few rumen bacterial strains have been shown capable of metabolizing 18:2n-6 to trans-10, cis-12 CLA, including P. acnes (Lourenço et al., 2010). The conversion of trans-10,cis-12 CLA to trans-10 18:1 may, however, be catalyzed by Butyrivibrio-related species (McKain et al., 2010). In this study, a T-RF compatible with the latter type of microorganisms, such as yet uncultured Lachnospiraceae strains, increased with $\mathrm{SOMA}_{2}$ and $\mathrm{SOMA}_{3}$ compared with the control, which is consistent with the changes reported in rumen fluid of sheep fed diets containing SO and fish oil (Belenguer et al., 2010). It is tempting to speculate that these bacteria are able to rapidly convert trans-10, cis-12 CLA to 18:1 isomers, mostly trans-10 18:1 (McKain et al., 
Table 7. Effect of diet supplementation with sunflower oil alone or in combination with incremental amounts of marine algae on the relative frequencies over the total peak area $(\%)$ of some terminal restriction fragments (T-RF) identified by terminal RFLP and potential compatible bacteria in rumen fluid of lactating ewes

\begin{tabular}{|c|c|c|c|c|c|c|c|c|c|}
\hline T-RF (bp) & $\begin{array}{l}\text { Compatible } \\
\text { bacteria }^{1}\end{array}$ & \multicolumn{5}{|c|}{ Treatment $^{2}$} & $\mathrm{SED}^{3}$ & $P$-value & Contrast $^{4}$ \\
\hline \multicolumn{10}{|l|}{ Total bacteria } \\
\hline $150+268(\mathrm{Msp} \mathrm{I})$ & Veillonellaceae & 6.45 & 3.78 & 13.30 & 10.25 & 16.56 & 4.633 & 0.08 & $\mathrm{~L}$ \\
\hline $244+288($ HaeIII $)$ & (Quinella-related) & $1.52^{\mathrm{b}}$ & $2.55^{\mathrm{b}}$ & $3.06^{\mathrm{ab}}$ & $6.43^{\mathrm{a}}$ & $7.37^{\mathrm{a}}$ & 2.103 & 0.04 & $\mathrm{~L}$ \\
\hline 309 (HaeIII) & & $6.34^{\mathrm{a}}$ & $4.06^{\mathrm{b}}$ & $2.37^{\mathrm{bc}}$ & $1.64^{\mathrm{c}}$ & $3.67^{\mathrm{b}}$ & 0.853 & $<0.001$ & $\mathrm{~L}$ \\
\hline $390(H h a \mathrm{I})$ & Unclassified & $1.94^{\mathrm{b}}$ & $4.97^{\mathrm{a}}$ & $4.28^{\mathrm{a}}$ & $1.35^{\mathrm{b}}$ & $2.07^{\mathrm{b}}$ & 1.043 & $<0.01$ & $\mathrm{~L}$ \\
\hline $227(M s p \mathrm{I})$ & Clostridiales & $0.98^{c}$ & $4.10^{\mathrm{ab}}$ & $5.20^{\mathrm{a}}$ & $1.69^{\mathrm{bc}}$ & $2.28^{\mathrm{bc}}$ & 1.311 & 0.02 & \\
\hline 276 (HaeIII) & & $8.00^{\mathrm{b}}$ & $17.11^{\mathrm{a}}$ & $10.21^{\mathrm{ab}}$ & $6.14^{\mathrm{b}}$ & $7.67^{\mathrm{b}}$ & 3.580 & 0.04 & $\mathrm{Q}$ \\
\hline \multicolumn{10}{|l|}{ Butyrivibrio (HhaI) } \\
\hline
\end{tabular}

${ }^{\mathrm{a}-\mathrm{c}}$ Within a row, different superscripts indicate significant differences $(P<0.05)$.

${ }^{1}$ Potentially compatible bacteria for each T-RF length pair and for the Butyrivibrio T-RF.

${ }^{2}$ Refers to TMR based on dehydrated alfalfa hay and concentrates containing no additional lipid (control), or supplemented with $25 \mathrm{~g}$ of sunflower oil and $0(\mathrm{SO}), 8\left(\mathrm{SOMA}_{1}\right), 16\left(\mathrm{SOMA}_{2}\right)$, or $24\left(\mathrm{SOMA}_{3}\right) \mathrm{g}$ of marine algae $(\mathrm{MA}) / \mathrm{kg}$ of diet DM.

${ }^{3} \mathrm{SED}=$ standard error of the difference.

${ }^{4}$ Indicates significant $(P<0.05)$ linear $(\mathrm{L})$ or quadratic $(\mathrm{Q})$ components of the response to incremental MA supplementation of a TMR containing sunflower oil estimated by orthogonal polynomial contrasts using data for $\mathrm{SO}, \mathrm{SOMA}_{1}, \mathrm{SOMA}_{2}$, and $\mathrm{SOMA}_{3}$ treatments.

2010), based on the lack of differences in the former between treatments. A low concentration of this CLA isomer in rumen fluid is in line with the low concentration in milk fat and provides further support that increases in ruminal outflow of trans-10, cis-12 CLA are not a major component of the decreases in mammary lipogenesis in lactating ewes fed SO and MA (Toral et al., 2010b).

The concentrations of 18:2n-6 and 18:3n-3 in the rumen fluid were lower on diets containing lipid supplements compared with the control treatment, which is in agreement with earlier measurements of rumen digesta

Table 8. Effect of diet supplementation with sunflower oil alone or in combination with incremental amounts of marine algae on the quantity of bacterial DNA ${ }^{1}$ of trans-11 18:1- and 18:0-producing Butyrivibrio determined by real-time PCR in rumen fluid of lactating ewes

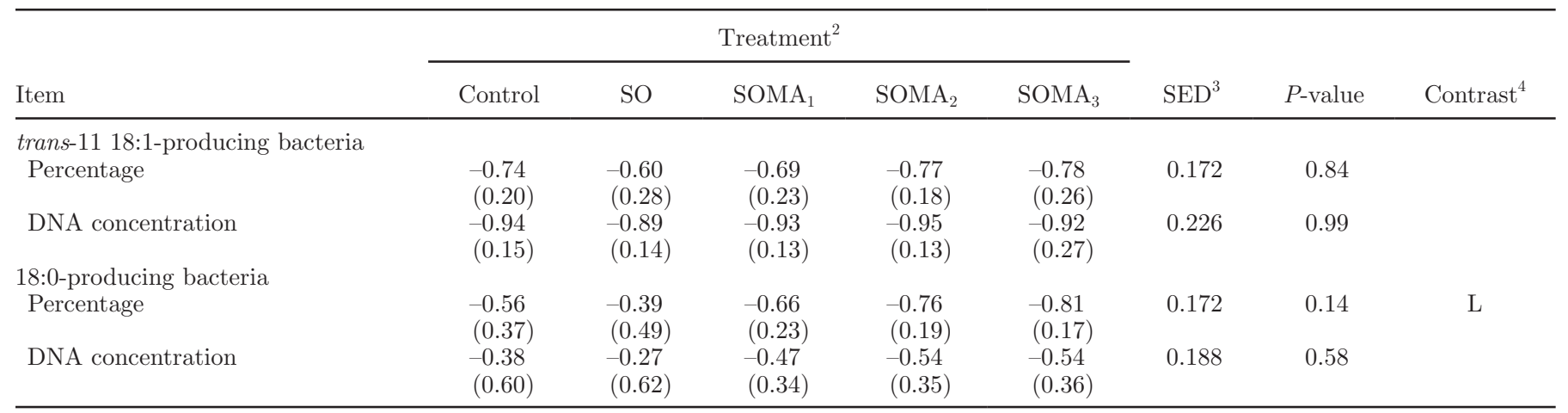

${ }^{1}$ Data are expressed as a $\log _{10}$ of the percentage (nontransformed values in parentheses) of the total genomic bacterial DNA and of the specific DNA concentration (pg/ng of total DNA; nontransformed values in parentheses) in total DNA.

${ }^{2}$ Refers to TMR based on dehydrated alfalfa hay and concentrates containing no additional lipid (control), or supplemented with $25 \mathrm{~g}$ of sunflower oil and $0(\mathrm{SO}), 8\left(\mathrm{SOMA}_{1}\right), 16\left(\mathrm{SOMA}_{2}\right)$, or $24\left(\mathrm{SOMA}_{3}\right) \mathrm{g}$ of marine algae $(\mathrm{MA}) / \mathrm{kg}$ of diet DM.

${ }^{3} \mathrm{SED}=$ standard error of the difference.

${ }^{4}$ Indicates significant $(P<0.05)$ linear $(\mathrm{L})$ or quadratic $(\mathrm{Q})$ components of the response to incremental MA supplementation of a TMR containing sunflower oil estimated by orthogonal polynomial contrasts using data for $\mathrm{SO}, \mathrm{SOMA}_{1}, \mathrm{SOMA}_{2}$, and $\mathrm{SOMA}_{3}$ treatments. 
FA composition in nonlactating sheep fed fish oil alone (Kitessa et al., 2001) or in combination with SO (Toral et al., 2010c). This may be the result of 2 effects: simple dilution due to SO and MA increasing total FA concentrations in the rumen or more extensive hydrogenation of dietary 18-carbon PUFA in the rumen in direct response to FA in the MA supplement, an effect that has been reported to occur in sheep fed diets containing fish oil (Chikunya et al., 2004; Sinclair et al., 2005).

In sheep, 22:6n-3 is hydrogenated to a lesser extent in the rumen when supplied as MA rather than fish oil in the diet (Sinclair et al., 2005). In cattle, ruminal BH of this PUFA has been reported to increase in direct relation to the amount of fish oil in the diet (Kim et al., 2008; Lee et al., 2008; Shingfield et al., 2010b). Inclusion of MA in the diet was associated with the appearance of $\Delta 10,13,1722: 3, \Delta 8,13,16,1922: 4$, cis-7,trans-13,cis16,cis-19 22:4, and trans-5,cis-10,cis-13,cis-16, cis-19 22:5, which supports earlier findings on the metabolic fate of 22-carbon PUFA in the rumen in sheep (Toral et al., 2010c) and lactating cows (Kairenius et al., 2011).

\section{CONCLUSIONS}

Supplementing the diet with SO alone or in combination with MA altered the FA composition of rumen fluid, an effect that was also associated with changes in populations of specific bacteria in lactating ewes. Inclusion of MA in diets containing SO resulted in the accumulation of trans 18:1 and 10-O-18:0 and in a marked decrease in 18:0 concentrations in rumen fluid. At the highest levels of supplementation (16 and $24 \mathrm{~g} /$ $\mathrm{kg}$ of $\mathrm{DM}), \mathrm{MA}$ also promoted a shift in ruminal $\mathrm{BH}$ pathways toward the formation of trans-10 18:1 at the expense of trans-11 18:1. Changes in the concentration of $\mathrm{BH}$ intermediates were not accompanied by significant variations in the abundance of known cultivated ruminal bacteria capable of hydrogenation of unsaturated FA. However, certain bacterial groups detected by T-RFLP (such as possibly uncultured Lachnospiraceae strains or Quinella-related bacteria) exhibited variations in their relative frequency consistent with a potential role in ruminal $\mathrm{BH}$.

\section{ACKNOWLEDGMENTS}

This work was supported by the Spanish Ministry of Science and Innovation (MICINN; AGL200804805-C02-02) and the Spanish National Research Council (CSIC; 200940I034). P. G. Toral was granted a fellowship from the CSIC (I3P Program). The authors thank R. John Wallace and Nest McKain from the Rowett Institute of Nutrition and Health (Aberdeen, UK), and C. Jamie Newbold from the Institute of Biological,
Environmental and Rural Sciences (Aberystwyth, UK) for kindly providing the bacterial strains.

\section{REFERENCES}

AbuGhazaleh, A. A., D. J. Schingoethe, A. R. Hippen, K. F. Kalscheur, and L. A. Whitlock. 2002. Fatty acid profiles of milk and rumen digesta from cows fed fish oil, extruded soybeans or their blend. J. Dairy Sci. 85:2266-2276.

Atkinson, R. L., E. J. Scholljegerde, S. L. Lake, V. Nayigihugu, B. W. Hess, and D. C. Rule. 2006. Site and extent of digestion, duodenal flow, and intestinal disappearance of total and esterified fatty acids in sheep fed a high-concentrate diet supplemented with highlinoleate safflower oil. J. Anim. Sci. 84:387-396.

Belenguer, A., P. G. Toral, P. Frutos, and G. Hervás. 2010. Changes in the rumen bacterial community in response to sunflower oil and fish oil supplements in the diet of dairy sheep. J. Dairy Sci. 93:3275-3286.

Boeckaert, C., V. Fievez, D. Van Hecke, W. Verstraete, and N. Boon. 2007. Changes in rumen biohydrogenation intermediates and ciliate protozoa diversity after algae supplementation to dairy cattle. Eur. J. Lipid Sci. Technol. 109:767-777.

Boeckaert, C., D. P. Morgavi, J. P. Jouany, L. Maignien, N. Boon, and V. Fievez. 2009. Role of the protozoan Isotricha prostoma, liquid-, and solid-associated bacteria in rumen biohydrogenation of linoleic acid. Animal 3:961-971.

Boeckaert, C., B. Vlaeminck, V. Fievez, L. Maignien, J. Dijkstra, and N. Boon. 2008. Accumulation of trans C-18:1 fatty acids in the rumen after dietary algal supplementation is associated with changes in the Butyrivibrio community. Appl. Environ. Microbiol. 74:6923-6930.

Castillo, M., S. M. Martin-Orue, M. Nofrarias, E. G. Manzanilla, and J. Gasa. 2007. Changes in caecal microbiota and mucosal morphology of weaned pigs. Vet. Microbiol. 124:239-247.

Chikunya, S., G. Demirel, M. Enser, J. D. Wood, R. G. Wilkinson, and L. A. Sinclair. 2004. Biohydrogenation of dietary n-3 PUFA and stability of ingested vitamin $\mathrm{E}$ in the rumen, and their effects on microbial activity in sheep. Br. J. Nutr. 91:539-550.

Cole, J. R., Q. Wang, E. Cardenas, J. Fish, B. Chai, R. J. Farris, A. S. Kulam-Syed-Mohideen, D. M. McGarrell, T. Marsh, G. M. Garrity, and J. M. Tiedje. 2009. The Ribosomal Database Project: Improved alignments and new tools for rRNA analysis. Nucleic Acids Res. 37:D141-D145.

Hill, T. C. J., K. A. Walsh, J. A. Harris, and B. F. Moffett. 2003. Using ecological diversity measures with bacterial communities. FEMS Microbiol. Ecol. 43:1-11.

Hongoh, Y., H. Yuzawa, M. Ohkuma, and T. Kudo. 2003. Evaluation of primers and PCR conditions for the analysis of $16 \mathrm{~S}$ rRNA genes from a natural environment. FEMS Microbiol. Lett. 221:299-304.

Hudson, J. A., C. A. M. MacKenzie, and K. N. Joblin. 1995. Conversion of oleic acid to 10-hydroxystearic acid by two species of ruminal bacteria. Appl. Microbiol. Biotechnol. 44:1-6.

Huws, S. A., E. J. Kim, M. R. F. Lee, M. B. Scott, J. K. S. Tweed, E. Pinloche, R. J. Wallace, and N. D. Scollan. 2011. As yet uncultured bacteria phylogenetically classified as Prevotella, Lachnospiraceae incertae sedis and unclassified Bacteroidales, Clostridiales and Ruminococcaceae may play a predominant role in ruminal biohydrogenation. Environ. Microbiol. 13:1500-1512.

Huws, S. A., M. R. F. Lee, S. M. Muetzel, T. W. Scott, R. J. Wallace, and N. D. Scollan. 2010. Forage type and fish oil cause shifts in rumen bacterial diversity. FEMS Microbiol. Ecol. 73:396-407.

Invernizzi, G., B. J. Thering, M. A. McGuire, G. Savoini, and J. J. Loor. 2010. Sustained upregulation of stearoyl-CoA desaturase in bovine mammary tissue with contrasting changes in milk fat synthesis and lipogenic gene networks caused by lipid supplements. Funct. Integr. Genomics 10:561-575.

Jenkins, T. C., R. J. Wallace, P. J. Moate, and E. E. Mosley. 2008. Board-invited review: Recent advances in biohydrogenation of unsaturated fatty acids within the rumen microbial ecosystem. J. Anim. Sci. 86:397-412. 
Kairenius, P., V. Toivonen, and K. J. Shingfield. 2011. Identification and ruminal outflow of long-chain fatty acid biohydrogenation intermediates in cows fed diets containing fish oil. Lipids 46:587-606.

Kim, E. J., S. A. Huws, M. R. F. Lee, J. D. Wood, S. M. Muetzel, R. J. Wallace, and N. D. Scollan. 2008. Fish oil increases the duodenal flow of long chain polyunsaturated fatty acids and trans-11 18:1 and decreases 18:0 in steers via changes in the rumen bacterial community. J. Nutr. 138:889-896.

Kitessa, S. M., S. K. Gulati, J. R. Ashes, E. Fleck, T. W. Scott, and P. D. Nichols. 2001. Utilisation of fish oil in ruminants: I. Fish oil metabolism in sheep. Anim. Feed Sci. Technol. 89:189-199.

Krumholz, L. R., M. P. Bryant, W. J. Brulla, J. L. Vicini, J. H. Clark, and D. A. Stahl. 1993. Proposal of Quinella ovalis gen. nov., sp. nov., based on phylogenetic analysis. Int. J. Syst. Bacteriol. 43:293-296.

Lee, M. R. F., K. J. Shingfield, J. K. S. Tweed, V. Toivonen, S. A. Huws, and N. D. Scollan. 2008. Effect of fish oil on ruminal biohydrogenation of $\mathrm{C} 18$ unsaturated fatty acids in steers fed grass or red clover silages. Animal 2:1859-1869.

Liu, S. J., D. P. Bu, J. Q. Wang, L. Liu, S. Liang, H. Y. Wei, L. Y. Zhou, D. Li, and J. J. Loor. Effect of incremental levels of fish oil supplementation on specific bacterial populations in bovine ruminal fluid. J. Anim. Physiol. Anim. Nutr. (Berl.) doi:10.1111/ j.1439-0396.2010.01113.x. In press.

Loor, J. J., A. Ferlay, A. Ollier, K. Ueda, M. Doreau, and Y. Chilliard. 2005. High-concentrate diets and polyunsaturated oils alter trans and conjugated isomers in bovine rumen, blood, and milk. J. Dairy Sci. 88:3986-3999.

Lourenço, M., E. Ramos-Morales, and R. J. Wallace. 2010. The role of microbes in rumen lipolysis and biohydrogenation and their manipulation. Animal 4:1024-1036.

Maeda, H., C. Fujimoto, Y. Haruki, T. Maeda, S. Kokeguchi, M. Petelin, H. Arai, I. Tanimoto, F. Nishimura, and S. Takashiba. 2003. Quantitative real-time PCR using TaqMan and SYBR Green for Actinobacillus actinomicetescomitans, Porphyromonas gingivalis, Prevotella intermedia, tetQ gene and total bacteria. FEMS Immunol. Med. Microbiol. 39:81-86.

McKain, N., K. J. Shingfield, and R. J. Wallace. 2010. Metabolism of conjugated linoleic acids and 18:1 fatty acids by ruminal bacteria: Products and mechanisms. Microbiology 156:579-588.

Or-Rashid, M. M., J. K. G. Kramer, M. A. Wood, and B. W. McBride. 2008. Supplemental algal meal alters the ruminal trans-18:1 fatty acid and conjugated linoleic acid composition in cattle. J. Anim. Sci. 86:187-196.

Paillard, D., N. McKain, L. C. Chaudhary, N. D. Walker, F. Pizette, I. Koppova, N. R. McEwan, J. Kopecny, P. E. Vercoe, P. Louis, and R. J. Wallace. 2007. Relation between phylogenetic position, lipid metabolism and butyrate production by different Butyrivibrio-like bacteria from the rumen. Antonie van Leeuwenhoek 91:417-422.

Reynolds, C. K., V. L. Cannon, and S. C. Loerch. 2006. Effects of forage source and supplementation with soybean and marine algal oil on milk fatty acid composition of ewes. Anim. Feed Sci. Technol. 131:333-357.

Schmidely, P., F. Glasser, M. Doreau, and D. Sauvant. 2008. Digestion of fatty acids in ruminants: A meta-analysis of flows and variation factors. 1. Total fatty acids. Animal 2:677-690.

Shingfield, K. J., S. Ahvenjärvi, V. Toivonen, A. Äröla, K. V. V. Nurmela, P. Huhtanen, and J. M. Griinari. 2003. Effect of dietary fish oil on biohydrogenation of fatty acids and milk fatty acid content in cows. Anim. Sci. 77:165-179.

Shingfield, K. J., L. Bernard, C. Leroux, and Y. Chilliard. 2010a. Role of trans fatty acids in the nutritional regulation of mammary lipogenesis in ruminants. Animal 4:1140-1166.

Shingfield, K. J., M. R. F. Lee, D. J. Humphries, N. D. Scollan V. Toivonen, and C. K. Reynolds. 2010b. Effect of incremental amounts of fish oil in the diet on ruminal lipid metabolism in growing steers. Br. J. Nutr. 104:56-66.

Shingfield, K. J., C. K. Reynolds, G. Hervás, J. M. Griinari, A. S. Grandison, and D. E. Beever. 2006. Examination of the persistency of milk fatty acid composition responses to fish oil and sunflower oil in the diet of dairy cows. J. Dairy Sci. 89:714-732.

Sinclair, L. A., S. L. Cooper, S. Chikunya, R. G. Wilkinson, K. G. Hallett, M. Enser, and J. D. Wood. 2005. Biohydrogenation of n-3 polyunsaturated fatty acids in the rumen and their effects on microbial metabolism and plasma fatty acid concentrations in sheep. Anim. Sci. 81:239-248.

Toral, P. G., P. Frutos, G. Hervás, P. Gómez-Cortés, M. Juárez, and M. A. de la Fuente. 2010a. Changes in milk fatty acid profile and animal performance in response to fish oil supplementation, alone or in combination with sunflower oil, in dairy ewes. J. Dairy Sci 93:1604-1615.

Toral, P. G., G. Hervás, P. Gómez-Cortés, P. Frutos, M. Juárez, and M. A. de la Fuente. 2010b. Milk fatty acid profile and dairy sheep performance in response to diet supplementation with sunflower oil plus incremental levels of marine algae. J. Dairy Sci. 93:16551667

Toral, P. G., K. J. Shingfield, G. Hervás, V. Toivonen, and P. Frutos, 2010c. Effect of fish oil and sunflower oil on rumen fermentation characteristics and fatty acid composition of digesta in ewes fed a high concentrate diet. J. Dairy Sci. 93:4804-4817.

Yang, S., S. Ma, J. Chen, H. Mao, Y. He, D. Xi, L. Yang, T. He, and W. Deng. 2010. Bacterial diversity in the rumen of Gayals (Bos frontalis), Swamp buffaloes (Bulbalis bulbalis) and Holstein cows as revealed by cloned $16 \mathrm{~S}$ rRNA gene sequences. Mol. Biol. Rep. $37: 2062-2073$. 